\title{
THE EFFECT OF GENOTYPE, SEX AND INTRAMUSCULAR FAT CONTENT ON THE COLOUR OF PORK
}

\author{
Libor Sládek ${ }^{1}$ Eliška Dračková1 \\ ${ }^{1}$ Department of Animal Breeding, Faculty of AgriSciences, Mendel University in Brno, Zemědělská 1, 61300 Brno, \\ Czech Republic
}

Link to this article: https://doi.org/10.11118/actaun202068010101

Received: 18. 12. 2019, Accepted: 4. 2. 2020

To cite this article: SLÁDEK LIBOR, DRAČKOVÁ ELIŠKA. 2020. The Effect of Genotype, Sex and Intramuscular Fat Content on the Colour of Pork. Acta Universitatis Agriculturae et Silviculturae Mendelianae Brunensis, 68(1): 101-108.

\begin{abstract}
The goal of this experiment was to establish the effect of genotype, sex and intramuscular fat (IMF) content in the musculus longissimus lumborum et thoracis (MLLT) on the colour of pork. The values of meat colour parameters were balanced in both gilts and barrows without significant differences $(p<0.05)$. The average value of the lightness parameter $L^{*}$ was $61.35 \pm 5.31$ in barrows in our research and $60.14 \pm 4.94$ in gilts. The percentage of yellow spectrum $b^{*}$ ranged within a narrow zone of from $13.67 \pm 2.14$ (gilts) to $13.88 \pm 2.02$ (barrows). The colour saturation value $\left(C^{*}\right)$ for meat from barrows $(14.42 \pm 2,33)$ differed by just 0.21 from the meat from gilts $(14.21 \pm 2.51)$. The lightest meat with the highest L* value, was from pigs to be slaughtered with the highest IMF content (5.00 to 9.50\%) $62.53 \pm 4.26$, or the group with a IMF content of 3.00 to $3.99 \%(62.12 \pm 4.96)$. The lightness value was lowest $(58.73 \pm 5.43)$ in the group with the lowest IMF content (1.85 to 2.99\%). To establish the effect of genotype on the colour of pork two hybrid combinations were monitored: $(C L W \times C L) \times D$ and $(C L W \times C L) \times(D \times B L)$. Different paternal lines in the groups did not affect any of the meat colour indicators significantly.
\end{abstract}

Keywords: colour of pork, hybrid combination, intramuscular fat

\section{INTRODUCTION}

The qualitative characteristics of meat during the fattening of animals to be slaughtered are influenced by a number of genetic and non-genetic factors. The species and breed, sex and age have the greatest significance, these influence the colour of the meat and its tenderness in particular. Meat from animals to be slaughtered exhibits great diversity in the quality indicators and properties of the meat, which result from the normal progress of post-mortem changes. Consumers consider the colour of the meat a very important indicator when purchasing meat (Balogh, 2016; Novotni-Danko, 2015) and its culinary use and physical parameters are directly affected by a number of zootechnical and technological factors. The colour is the primary stimulus for selection of butchered, particularly portioned meat by consumers, who prefer meat with a pale pink colour over dark coloured meat. Colour is an important criterion for consumers and depends on the concentration and oxidation level of myoglobin and on the structure of the meat (Ruiz De Huidobro et al., 2003). The colour of the meat chiefly depends on the content of hemo-pigments (Šimek and Steinhauser, 2001). The most widespread hemo-pigments are haemoglobin and myoglobin (the pigments in muscle tissue). Eder (2004) states that the colour of the meat is an important indicator of its freshness. The amount of myoglobin in animal muscles determines the colour of the meat. Pork is classified as a red meat, because it contains more myoglobin than chicken or fish. 
When fresh pork is cooked, the juice is lighter, but it is still red meat. As well as other factors, myoglobin content is also dependent on the breed, sex, type of muscle, movement (muscles used more often contain more myoglobin) and nutrition. A number of authors focused on the effect of breed and sex on the colour of pork: Lertpatarakomol et al. (2019), Kima et al. (2009), Ruusunen (2012), Corino et al. (2008), Serrano et al. (2008), Fortina et al. (2005), Martin et al. (2008) and others. Pork from purebred Duroc or from Duroc hybrids is usually darker than pork from Landrace or Yorkshire pigs Blanchard et al. (1999), Newcom et al. (2004), which is also related to the higher final pH of pork from the Duroc breed, as stated by some studies CandekPotokar et al. (1998), Newcom et al. (2004).

High importance for taste and crispness of meat has an intramuscular fat especially its intercellular portion with deposition in a form of small veins which create meat marbling. According to Suzuki et al. (2005) and Woode et al. (2008) intramuscular fat is on of the main parameters with an influence on sensor characters and meat quality. On a base of tasting tests it is recommended a level of 2.5\% of IMF in MLLT as is mentioned in Bejerholm and Barton Gade (1986). From pure breeds only Duroc is reaching this level (Bečková, 1997). Suzuki et al. (2005) mention in their study that Duroc is reaching the highest values of IMF content in comparison with other pig breeds. Lo et al. (1992), Armero et al. (1998) mention in their studies higher content of IMF (2.4-4.5\%) in Duroc breed in comparison with Large White and Landrace too. Also the hybrids with Duroc have higher content of IMF in comparison with hybrids of other breeds.

\section{MATERIALS AND METHODS}

We monitored selected carcass value and pork colour indicators to establish their dependence on sex and IMF content. The pigs were divided into two groups by sex. The group of barrows numbered 55 and the $2^{\text {nd }}$ group consisted of 61 gilts.

To establish the effect of genotype on the colour of pork two hybrid combinations were monitored: F1 generation hybrids of Czech Large White $\times$ Czech Landrace (CLW $\times$ CL) were used as mothers and were bred by insemination to boars of the Duroc (D) breed using insemination batches from the boar insemination station in Velké Meziříćí, boars of the Duroc breed and Duroc $\times$ Belgium Landrace $(\mathrm{D} \times \mathrm{BL})$ hybrids. 30 pigs for slaughter were monitored within the terms of individual experimental hybrid combinations.

After birth the experimental piglets were individually tagged with an identification number and the animal's sex was recorded in a created database.

After the animals had been fattened the tested pigs were slaughtered at the slaughter house in Kostelec u Jihlavy. After being slaughtered the weight of the carcass was established and the slaughter weight of the slaughtered pig was established using a coefficient (1.285).

The percentage of muscle tissue was also determined in the individual tested animals using invasive methods by means of a Fat-o-Meater FOM probe, which established and recorded the values measured in the carcass by optical electronic methods and which works invasively, i.e the probe must be inserted into the carcass to determine the measured values.

When butchering the pig carcasses $300 \mathrm{~g}$ samples from the MLLT were taken from the carcases of 176 tested animals at the point of the last thoracic vertebra to assess the quality of the meat.

In relation to the qualitative indicators, we focused on establishing $\mathrm{pH}$ values ${ }_{1}$ in the MLLT and specification of the IMF content, which took place in a laboratory at Mendel University in Brno at the Institute of Animal Breeding. IMF content was determined by direct extraction according to Soxhlet using ether. $\mathrm{pH}_{1}$ was measured 45 minutes after the slaughtered test pig was killed.

The pigs were divided into four groups depending on the IMF content. The $1^{\text {st }}$ group consisted of 33 pigs with an IMF content ranging from 1.85 to $2.99 \%$, the $2^{\text {nd }}$ group consisted of 39 pigs with an IMF content ranging from 3.00 to $3.99 \%$. The third group, with an IMF content ranging from 4.00 to $4.99 \%$, had 33 pigs and the last group with an IMF content ranging from 5.00 to $9.50 \%$ consisted of 11 individuals.

Parameters in the CIE L* $\mathrm{a} * \mathrm{~b}^{*}$ colour system were monitored in order to evaluate the colour of the pork, whereas lightness $\left(\mathrm{L}^{*}\right)$, the percentage of the red $\left(\mathrm{a}^{*}\right)$ and yellow $\left(b^{*}\right)$ spectrum, the saturation value $\left(\mathrm{C}^{*}\right)$ and the hue angle (h) as determined by a Konica Minolta CM - 2600d spectrometer (Konica Minolta, Japan), were monitored. In order to ensure standard conditions when taking these measurements the gauge aperture was set to $8 \mathrm{~mm}$, the source of daylight was - D65, $10^{\circ}$ standard observer angle and SCI mode were set.

The data we obtained from the analyses was mathematically processed by means of STATISTICA10 software using variance analysis with fixed effects. An HSD test was used to determine the significance of differences between individual groups and the probability of differences was determined at a level of $\mathrm{p}<0.05$ and $\mathrm{p}<0.01$.

Statistical model:

$$
Y_{i j k l}=\mu+P O_{i}+T_{j}+O_{k}+e_{i j k l}
$$

whereas:

$Y$........resulting corrected value;

$\mu$........average value of the dependent variable $P O_{i}=$ sex (gilts, barrows);

$T_{j}$......intramuscular fat content (1.85-2.99\%; 3.00-3.99\%, 4.00-4.99\%, 5.00-9.50\%);

$\mathrm{O}_{k} \ldots . .$. paternal line (D, D $\times \mathrm{BL}$ );

$e_{i j k l} \ldots . .$. residue. 


\section{RESULTS AND DISCUSSION}

Tab. I gives a summary of the monitored carcass value and meat colour indicators depending on the sex of the pigs. The average slaughter weight of the barrows was $123 \pm 8.90 \mathrm{~kg}$, i.e. $4 \mathrm{~kg}$ higher than the weight of gilts $(119 \pm 9.33 \mathrm{~kg})$ and statistical significance on the level of 95\% probability was established. Sládek et al. (2008) published a lower weight for two hybrid combinations of barrows and gilts at the end of fattening. The carcasses of barrows weighed $96 \pm 6.93 \mathrm{~kg}$ and gilts weighed $93 \pm 7.26 \mathrm{~kg}$, conclusive differences between the sexes were proven here $(p<0.05)$. Muscle mass (the proportion of lean meat) was higher in gilts $(58.90 \pm 1.82 \%)$ than in barrows $(56.91 \pm 2.72 \%)$ and very significant differences were recorded ( $p<0.01)$. When comparing the lean meat percentage in the carcass of barrows compared to gilts, authors Lertpatarakomol et al. (2019), Daumas et al. (1998), Correa et al. (2006), Václavková and Bečková (2009) and Vališ et al. (2008) came to the same proportions as those established in our experiment. They found that the carcass of gilts contains more muscle than the carcass of barrows, but at various levels of statistical significance.

With regard to the fact that meat colour is also more significantly influenced by $\mathrm{pH}_{1}$, we also included this quality indicator. Meat with a lower $\mathrm{pH}$ value $_{1}$ has a greater light variance and gives the impression of being paler (Jedlička, 1988). The effect of sex on $\mathrm{pH}_{1}$ was not proven and $\mathrm{pH}_{\text {values }}$ in barrows $(6.18 \pm 0.30)$ and gilts $(6.11 \pm 0.31)$ exhibited a very low inter-group variability. Bučko et al. (2009) came to similar conclusions. Mlynek et al. (2009) found a $\mathrm{pH}_{1}$ of 6.23 and 6.30 in a nutritional experiment in gilts $(\mathrm{LW} \times \mathrm{L}) \times \mathrm{PIC}$. Šimek et al. (2004) monitored $\mathrm{pH}_{1}$ in four groups of hybrids and their pH value was lower: 5.9.

In our experiment we established a very uniform intramuscular fat (IMF) content with no statistical significance $(p<0.05)$; in gilts $(3.62 \pm 1.21 \%)$ and in barrows $(3.83 \pm 1.16)$. Mlynek et al. (2009) give a lower average IMF content in gilts (1.00\%). As in our case, Correa et al. (2006) established statistical significance $(p<0.05)$ in their study between barrows and gilts of the hybrid combination $\mathrm{D} \times(\mathrm{L} \times$ Yorkshire $)$. Significance at a level of 95\% between sexes in IMF was also proven by Vališ et al. (2008). Matoušek et al. (2006) state that in their experiment they found that barrows had a $0.25 \%$ higher percentage of IMF than gilts $(1.35 \%$ or 1.09\%). Alvarez-Rodríguez and Teixeirab (2019) also state in their publication that they recorded a higher IMF content between sexes (1.44\%) compared to gilts (1.20) in the Bisaro breed they monitored.

Tab. I gives the results of individual pork colour indicators. The values of meat colour parameters were balanced in both gilts and barrows, without significant differences $(\mathrm{p}<0.05)$. This fact was also proven in the experiment by Correa et al. (2006), who did not find conclusive differences between the sexes. The following average values were measured in both sexes $L^{*} 50.60 ; a^{*} 7.02$ and $b^{*} 4,30$. The average value of the lightness parameter $L^{*}$ was $61.35 \pm 5.31$ in barrows in our research and $60.14 \pm 4.94$ in gilts. Lertpatarakomol et al. (2019) gives L* values for gilts as 50.67 and for barrows as 53.16, and b* values for gilts as 11.67 and 12.08 for barrows, in his work. Vítek et al. (2009) recorded a value of 61.88 in the $L^{*}$ parameter in a sample of pigs consisting of barrows and gilts. The meat of barrows exhibited a 1.21 lighter colour than the meat of gilts. The red spectrum percentage $a^{*}$ was $3.43 \pm 2.24$ in gilts and $3.56 \pm 2.01$ in barrows. In his study Karamucki (2013) states that the sex of the animals influences the formation of the colour of the pork. On the basis of our observations we came to the conclusion that the meat of gilts is darker than the colour of the meat of barrows.

In their publication Langlois and Minivielle (1989) mention the darker colour of meat from gilts compared to meat from barrows of the breeds Duroc, Hampshire, Landrace and Large White, on the contrary to studies by the authors Eikelenboom and Hoving-Bolink (1993), Hammel, Laforest and Dufor (1994), who did not find any differences in pork colour between gilts and barrows of various hybrids in their experiments.

The yellow spectrum percentage $\mathrm{b}^{*}$ in our slaughtered pigs fell within a narrow range from $13.88 \pm 2.02$ (barrows) to $13.67 \pm 2.14$ (gilts). The colour saturation value $\left(C^{*}\right)$ in meat from barrows (14.42 $\pm 2,33)$ differed by just 0.21 from the meat from gilts $(14.21 \pm 2.51)$. The hue angle (h) had a value of $76.46 \pm 6.88$ in meat from barrows and $76.92 \pm 7.52$ in meat from gilts.

Latorre et al. (2003) slaughtered barrows and gilts of the hybrid combination (Danish Landrace $\times$ Pietrain) $\times$ Large White of an average weight of $117 \mathrm{~kg}$ in their experiment. They proved significant differences between the sexes $(p<0.001)$ in the evaluation of IMF (3.4 and 2.7\%) and in some of the meat colour parameters. Lightness values $\mathrm{L}^{*}$ were determined in groups on the level of 47.1 and 47.1; values for $\mathrm{a}^{*}$ at the level of 4.11 and 4.49, with a statistical significance for inter-group differences ( $p$ < 0.01); b* values at 8.32 and 8.09 and $C^{*}$ values at 9.29 and 9.27 .

Kima et al. (2009) fattened pigs of the Korean Black breed. The authors established the following meat colour parameters at a meat $\mathrm{pH}_{1}$ value of 5.7: L*: 53.57, a*: 6.81 and b*: 2.93. Serrano et al. (2008) evaluated meat colour parameters in hybrids between the Iberian $\times$ Duroc breeds. In groups arranged according to the sex of the pigs the authors of the work determined quite significant differences $(p<0.05)$ between barrows and gilts for the values: $L^{*}$ (44.3 and 44.8), a* (7.4 and 7.1), b* (12.9 and 13.9) and $C^{*}$ (13.6 and 15.5). Intergroup differences in $\mathrm{h}$ values (60.9 and 61.6) were statistically insignificant. 
The results of pork colour parameters depending on IMF content are given in Tab. II. The lightest meat, with the highest $\mathrm{L}^{*}$ value was found in the last group with the highest IMF content (5.00 to $9.50 \%$ ) $62.53 \pm 4.26$, or more precisely in the group with a IMF content ranging from 3.00 to $3.99 \%$ (62.12 \pm 4.96). The lightness value was lowest $(58.73 \pm 5.43)$ in the group with the lowest IMF content (1.85 to $2.99 \%)$. For the lightness parameter a statistical conclusiveness ( $p<0.05$ ) was proven between group 1 (the least fat) and group 4 (the most fat), or group 2 (up to 4\% fat). Šprysl et al. (2011) slaughtered pigs at a lower average CC weight of $89.8 \mathrm{~kg}$, with a lower IMF content of $2.1 \%$ and with a lower colour lightness of $\mathrm{L}^{*} 57.27$.

The red spectrum percentage $\left(a^{*}\right)$ in the pigs we tested fluctuated significantly with no linear dependence. In the first group this value was $2.56 \pm 2.28$, in the second group it was $4.01 \pm 1.78$, in the third group it was $3.76 \pm 2.13$ and in the fourth group it was $3.62 \pm 2.10$. Significance at a level of 95\% was established between group 1 (1.85 to $2.99 \%$ fat) and group 2 (3.00 to $3.99 \%$ fat). The parameters of the percentage of yellow spectrum $\left(b^{*}\right)$ exhibited a statistical difference $(\mathrm{p}<0.05)$ between the group with the lowest amount of IMF $12.87 \pm 2.24$ and the group with the highest amount of IMF in muscle tissue $14.47 \pm 2.01$, or the second group $14.25 \pm 1.90$. Similar statistical significance $(p<0.05)$ between group 1 and group 4, or group 2, was established for meat colour saturation $\left(\mathrm{C}^{*}\right)$, where the level ranged from $13.26 \pm 2.56$ ( $1^{\text {st }}$ group) to $15.00 \pm 2.35$ ( $4^{\text {th }}$ group). The hue angle (h) showed a difference on just the level of $95 \%$ between group 1 (79.97 \pm 8.43$)$ and group $2(74.84 \pm 5.62)$. The lowest values of meat lightness in the test group were established by Adamec et al. (2011) - L $^{*}$ 54.84, other meat colour spectrum values at a $\mathrm{pH}_{1}$ of 5.69 , corresponded more to the first group of pigs (a* 2.39; b* 12.65) in our experiment. A similar $L^{*}$ value (57.87) to the value established in our experiment was established by Lehotayová et al. (2012) at $\mathrm{pH}_{1}$ values of 6.20, but the values were higher for pork spectral parameters ( $a^{*} 6.86$; $b^{*}$ 3.76). In their work the authors determined the effect of the temperature of the environment $\left(30^{\circ} \mathrm{C}\right)$ on pork colour indicators ( $L^{*} 55.86$; $\mathrm{a}^{*} 4.20$; $\mathrm{b}^{*} 7.71$; $\mathrm{pH}_{1}$ 6.29).

Different paternal lines in the groups did not affect any of the meat colour indicators as is clear from Tab. III. No statistical significance was established ( $p<0.05$ ), the values of the measured parameters compared among groups were very similar. The lightness parameter $L^{*}$ exhibited the value of $58.32 \pm 3.28$ in pigs to be slaughtered of the hybrid combination $(C L W \times C L) \times D$ and the value $59.92 \pm 4.81$ in the hybrid combination $(\mathrm{CLW} \times \mathrm{CL}) \times(\mathrm{D} \times \mathrm{BL})$. Jankowiak et al. (2009) established the meat lightness of hybrids (PLW $\times$ PL) at just the level of $52.54 \%$.

In our experiment the red spectrum percentage $a^{*}$ was $1.11 \pm 1.73$ for the 1 st group with boars from the Duroc breed and $1.32 \pm 1.52$ in the $2^{\text {nd }}$ group with hybrid boars $\mathrm{D} \times \mathrm{BL}$. We determined the yellow spectrum percentage $\mathrm{b}^{*}$ at the level of $12.30 \pm 1.35$ in the $1^{\text {st }}$ group and $12.86 \pm 1.77$ in the $2^{\text {nd }}$ hybrid group. Within the scope of the groups the saturation value $C^{*}$ fell within the narrow range of $12.45 \pm 1.49$ ( $1^{\text {st }}$ group) and $12.99 \pm 1.88$ ( $2^{\text {nd }}$ group $)$. Nor did the hue angle values change much between groups; the difference between the groups was 0.74 degrees (85.48 \pm 7.36 the D group and $84.74 \pm 6.13$ for the $\mathrm{D} \times \mathrm{BL}$ group).

Thomas et al. (2019) determined the lightness value $L^{*}$ as falling within the range of (38.91-53.75), value $a^{*}(6.83-11.96)$ and value $b^{*}(11.38-18.49)$ in hybrid combinations (Ghungroo $\times$ Hampshire $\times$ Duroc) of pigs to be slaughtered at 10 months of age.

Bocian et al. (2018) evaluated the quality of meat from 52 fattened hybrids of the F1 generation (Polish Large White $\times$ Polish Landrace) and established the following values: IMF $2.35 \%, L^{*} 53.95 \pm 2.4$, a* $14.95 \pm 0.99, b * 2.79 \pm 0.73, C^{*} 15.23 \pm 1.01$, h $10.57 \pm 2.63$.

Renaudeau et al. (2007) evaluated the quality of meat in the Creole and Large White (LW) breeds. In relation to meat colour indicators the differences in parameters were insignificant and fairly uniform ( L $^{*}-66.2$ and 67.1; $\mathrm{a}^{*}-9.36$ and 9.70; b* -7.70 and 8.10). Differences in the monitored meat colour indicators were also insignificant when evaluating differences between sexes ( $L^{*} 66.6$ and 66.8; $a^{*} 9.21$ and 9.86; $b * 7.76$ and 8.02.).

Olivas (2017) et al. established the physicalchemical properties of pork at various commercial centres in Ciudad Obregon (Mexico). They collected 50 samples of meat from 10 various shopping centres. The measured the following values in colour indicators: $\mathrm{L} * 48.97 \pm 4.20, \mathrm{a} * 3.95 \pm 1.15$ and $\mathrm{b} * 11.22 \pm 0.49$.

Ruusunen et al. (2012) fattened 4 hybrids of sows (Landrase $\times$ Yorkshire $(\mathrm{Y})$ ) and 4 boars: Finnish Landrace (FL), Norwegian Landrace (NL), Norwegian Duroc $\times$ Norwegian Landrace (DNL), Swedish Hampshire (SH). More significant $(p<0.05)$ inter-group differences (FL group and NL, DNL and $\mathrm{SH}$ groups) were determined between the groups by hybrid when evaluating parameter $L^{*}$ (50.6; 48.1; 47.6 and 46.3) and in parameter $a^{*}$ (7.4; 7.0; 7.1 and 8.4) between the SH group and the FL, NL and DNL groups. 
I: Key characteristic of slaughter value and meat colour indicators according to the sex of the pigs

\begin{tabular}{|c|c|c|}
\hline \multirow{2}{*}{ Traits } & Barrows $(n=55)$ & Gilts $(n=61)$ \\
\hline & $\mathrm{x} \pm \mathrm{SE}$ & $\mathrm{x} \pm \mathrm{SE}$ \\
\hline Slaughter weight (kg) & $123^{\mathrm{a}} \pm 8.90$ & $119^{b} \pm 9.33$ \\
\hline Carcass weight (kg) & $96^{\mathrm{a}} \pm 6.93$ & $93^{\mathrm{b}} \pm 7.26$ \\
\hline Proportion of lean meat (\%) & $56.91^{\mathrm{A}} \pm 2.72$ & $58.90^{\mathrm{B}} \pm 1.82$ \\
\hline $\mathrm{pH}_{1}$ & $6.18 \pm 0.30$ & $6.11 \pm 0.31$ \\
\hline Intramuscular fat (\%) & $3.83 \pm 1.16$ & $3.62 \pm 1.21$ \\
\hline $\mathrm{L}^{*}$ & $61.35 \pm 5.31$ & $60.14 \pm 4.91$ \\
\hline$a^{*}$ & $3.56 \pm 2.01$ & $3.43 \pm 2.24$ \\
\hline $\mathrm{b}^{*}$ & $13.88 \pm 2.02$ & $13.67 \pm 2.14$ \\
\hline $\mathrm{C}^{*}$ & $14.42 \pm 2.33$ & $14.21 \pm 2.51$ \\
\hline h & $76.46 \pm 6.88$ & $76.92 \pm 7.52$ \\
\hline \multicolumn{3}{|c|}{$\begin{array}{l}\text { Statistical significance between the evaluated groups of pigs: } A, B=p<0.01, a, b=p<0.05, x-\text { Average, } S E-\text { Standard } \\
\text { deviation, } n \text { - Number, } L^{*} \text { - Lightness parameter, } a^{*} \text { - value of red spectrum in the meat, } b^{*}-\text { Yellow spectrum percentage, } \\
C^{*}-\text { Saturation value, } h \text { - Hue angle. }\end{array}$} \\
\hline
\end{tabular}

\begin{tabular}{|c|c|c|c|c|}
\hline \multirow[b]{2}{*}{ Traits } & \multicolumn{4}{|c|}{ IMF content $(\%)$} \\
\hline & $\begin{array}{c}1.85-2.99 \\
(\mathrm{n}=33)\end{array}$ & $\begin{array}{c}3.00-3.99 \\
(\mathrm{n}=39)\end{array}$ & $\begin{array}{c}4.00-4.99 \\
(\mathrm{n}=33)\end{array}$ & $\begin{array}{c}5.00-9.50 \\
(\mathrm{n}=11)\end{array}$ \\
\hline & $\mathrm{x} \pm \mathrm{SE}$ & $\mathrm{x} \pm \mathrm{SE}$ & $\mathrm{x} \pm \mathrm{SE}$ & $\mathrm{x} \pm \mathrm{SE}$ \\
\hline $\mathrm{L}^{*}$ & $58.73^{a} \pm 5.43$ & $62.12^{b} \pm 4.96$ & $60.44 \pm 4.70$ & $62,53^{b} \pm 4.26$ \\
\hline$a^{*}$ & $2.56^{\mathrm{a}} \pm 2.28$ & $4.01^{b} \pm 1.78$ & $3.76 \pm 2.13$ & $3.62 \pm 2.10$ \\
\hline $\mathrm{b}^{*}$ & $12.87^{a} \pm 2.24$ & $14.25^{b} \pm 1.90$ & $13.85 \pm 1.91$ & $14,47^{b} \pm 2.01$ \\
\hline $\mathrm{C}^{*}$ & $13.26^{a} \pm 2.56$ & $14.87^{b} \pm 2.19$ & $14.45 \pm 2.30$ & $15.00^{b} \pm 2.35$ \\
\hline $\mathrm{h}$ & $79.97^{a} \pm 8.43$ & $74.84^{b} \pm 5.62$ & $75.63 \pm 6.86$ & $76,73 \pm 6.71$ \\
\hline
\end{tabular}

Statistical significance between the evaluated groups of pigs: $a, b=p<0.05, x-$ Average, SE - Standard deviation, $n$ - Number, $L^{*}$ - Lightness parameter, $a^{*}$ - value of red spectrum in the meat, $b^{*}$ - Yellow spectrum percentage, $\mathrm{C}^{*}$ - Saturation value, h: Hue angle.

III: Characteristics of pork colour indicators by paternal line

\begin{tabular}{|c|c|c|}
\hline Traits & $\mathrm{D}(\mathrm{n}=30)$ & $\mathrm{D} \times \mathrm{BL}(\mathrm{n}=30)$ \\
\hline & $\mathrm{x} \pm \mathrm{SE}$ & $\mathrm{x} \pm \mathrm{SE}$ \\
\hline $\mathrm{L}^{*}$ & $58.32 \pm 3.28$ & $59.92 \pm 4.81$ \\
\hline$a^{*}$ & $1.11 \pm 1.73$ & $1.32 \pm 1.52$ \\
\hline $\mathrm{b}^{*}$ & $12.30 \pm 1.35$ & $12.86 \pm 1.77$ \\
\hline $\mathrm{C}^{*}$ & $12.45 \pm 1.49$ & $12.99 \pm 1.88$ \\
\hline $\mathrm{h}$ & $85.48 \pm 7.36$ & $84.74 \pm 6.13$ \\
\hline
\end{tabular}

\section{CONCLUSION}

The CIE L*a* b* method was used to measure the colour of pork during the executed experiments in fattening pigs. No significant differences in any of the parameters of the aforementioned method were determined between barrows and gilts in fattening pigs. The value of meat lightness $L^{*}$ in barrows and gilts was nearly identical and therefore without significant differences between the groups. Higher, but statistically insignificant, values of the percentage of red spectrum a* were 
assessed in gilts, which indicates a slightly darker shade of red colour to the meat, in relation to a lower IMF content in the experimental group. In relation to an overall evaluation of changes in pork colour parameters, only minimal differences in values were recorded and we can state that practically no differences in meat colour between barrows and gilts, fattened to an average weight of $110 \pm 3 \mathrm{~kg}$, were determined in the executed experiment.

We also monitored the possibility of the effect of various IMF content on meat colour parameters. During detailed analysis of the link between meat colour and IMF content we recorded the significantly lightest meat, with the highest L* value, in the group with the highest fat content (5.00 to 9.50\%), or in the group with a IMF content of from 3.00 to $3.99 \%$. The lightness of the meat was lowest (58.73) in the group with the lowest IMF content (1.85 to 2.99\%). Statistical significance ( $<0.05)$ was proven for the lightness parameter between group 1 (lowest IMF content) and group 4 (highest IMF content), or group 2 (up to 4\% fat). The parameters of the percentage of yellow spectrum (b*) exhibited a statistical difference $(\mathrm{p}<0.05)$ between the group with the lowest amount of IMF and the group with the highest amount of fat in muscle tissue. Similar statistical significance $(p<0.05)$ between group 1 and group 4, or group 2, was established for meat colour saturation $\left(\mathrm{C}^{*}\right)$.

Another part of the experiment in fattening pigs was determination of the possibility of the effect of transfer of genetic information from the sires to the offspring on meat colour, i.e the influence of the paternal line in hybrid pigs. The evaluated paternal lines of pigs (Duroc sire breed and Duroc $\times$ Belgian Landrace hybrid sire) did not affect any of the meat colour indicators.

\section{REFERENCES}

ADAMEC, T., DOLEJŠ, J., TOUFAR, O. et al. 2011. Electrically treated water in pig farming and pig meat quality. Research in Pig Breeding, 5(1): 1-3.

ÁLVAREZ-RODRÍGUEZA, J. and TEIXEIRAB, A. 2019. Slaughter weight rather than sex affects carcass cuts and tissue composition of Bisaro pigs. Meat Science, 154: 54-60.

ARMERO, E., FLORES, M., BARBOSA, J. A. et al. 1998. Effects of terminal pig sire types and sex: On carcass traits, meat quality and sensory analysis of dry-cured ham. In: $44^{\text {th }}$ Int. Cong. Meat Science and Technology. Barcelona, pp. 904-905.

BALOGH, P., BÉKÉSI, D., GORTON, M. P. et al. 2016. Consumer willingness to pay for traditional food products. Food Policy, 61: 176-184.

BEČKOVÁ, R. 1997. Možnosti zlepšování kvality vepřového masa. Náš chov, 8: 17-19.

BEJERHOLM, C. and BARTON-GADE, P. 1986. Effect of intramuscular fat level on eating quality of pig meat. In: 32 nd European Meeting Meat Research Workers. Ghent, Belgium, pp. 389-391.

BLANCHARD, P. J., WARKUP, C. C., ELLIS, M. et al. 1999. The influence of rate of proportion of Duroc genes on growth, carcass and pork eating quality. Animal Science, 68(3): 495-501.

BOCIAN, M., JANKOWIAK, H., RESZKA, P. et al. 2018. Pork quality with special emphasis on colour and its changes during storage. Journal of Central European Agriculture, 19(1): 102-113.

BUČKO, O., VAVRIŠINOVÁ, K., MLYNEK, J. et al. 2009. The characterisation of production traits and technological quality traits of pork in BM breed, divided by polymorphism hal gene allele. Research in Pig Breeding, 3(1): 1-7.

CANDEK-POTOKAR, M., ZLENDER, B. and BONNEAU, M. 1998. Effects of breed and slaughter weight on longissimus muscle biochemical traits and sensory quality in pigs. Annales de Zootechnie, 47(1): 3-16.

CORINO, C., MUSELLA, M., PASTORELLI, G. et al. 2008. Influences of dietary conjugated linoleic acid (CLA) and total lysine content on growth, carcass characteristics and meat quality of heavy pigs. Meat Science, 79(2): 307-316.

CORREA, J. A., FAUCITANO, L., LAFOREST, J. P. et al. 2006. Effects of slaughter weight on carcass composition and meat quality in pigs of two different growth rates. Meat Science, 72(1): 91-99.

DAUMAS, G., CAUSER, D., DHORNE, T. et al. 1998. Les methodes de classement des carcasses de porc autorisees en France en 1997. Journées de la Recherche Porcine en France, 30: 1-6.

EDER, R. 2004. Pigments. In: NOLLET, L. M. L. (Ed.). Handbook offood analysis. Physical characterization and nutriet analysis.Volume 1. New York: Marcel Dekker, pp. 860-877.

EIKELENBOOM, G. and HOVING-BOLINK, R. 1993. Schweinefleischqualität. Einflüsse der Futterzuzammensetzung, des Geschlechts und des Zeitpunkts der Schlachtung. Fleischwirtschaft, 73: 648-650.

FORTINA, R., BARBERA, S., LUSSIANA, C. et al. 2005. Performances and meat quality of two Italian pig breeds fed diets for commercial hybrids. Meat Science, 71(4): 713-718. 
HAMMELL, K. L., LAFOREST, J. P. and DUFOR, J. J. 1994. Evaluation of lean meat colour of commercial pigs produced in Quebec. Canadian Journal of Animal Science, 74: 443-449.

JANKOWIAK, H., KAPELAŃSKI, W., KWIATKOWSKA, B. E. et al. 2009. Carcass and meat quality of Złotnicka Spotted pigs in comparison to Polish Large White x Polish Landrace crossbred pigs. Research in Pig Breeding, 3(2): 4-6.

JEDLIČKA, J., 1988: Kvalita mäsa z hl'adiska prvovýrobcu, spracovatela a konzumenta. Monography. $1^{\text {st }}$ Edition. Bratislava: Príroda.

KARAMUCKI, T., GARDZIELEWSKA, J., JAKUBOWSKA, M. et al. J. 2013. The relationship between colour and pH in cold-stored quail breast muscle. Annals of Animal Science, 13(2): 401-413.

KIMA, D. H., SEONGA, P. N., CHOA, S. H. et al. 2009. Fatty acid composition and meat quality traits of organically reared Korean native black pigs. Livestock Science, 120(1-2): 96-102.

LANGLOIS, A. and MINIVIELLE, F. 1989. Comparisons of three-way and backcross swine: II. wholesale cuts and meat quality. Journal of Animal Science, 67(8): 2025-2032.

LATTORE, M. A., LÁZARO, R., GRACIA, M. I. et al. 2003. Effect of sex and terminal sire genotype on performance, carcass characteristics and meat quality of pigs slaughtered at $117 \mathrm{~kg}$ body weight. Meat Science, 65(4): 1369-1377.

LERTPATARAKOMOL, R., CHAOSAP, C., CHAWEEWAN, K. et al. 2019. Carcass characteristics and meat quality of purebred Pakchong 5 and crossbred pigs sired by Pakchong 5 or Duroc boar. Asian-Australasian Journal of Animal Science, 32(4): 585-591.

LEHOTAYOVÁ, A., BUČKO, O., PETRÁK, J. et al. 2012. Effect of high ambient temperature on meat quality of pigs. Research in Pig Breeding, 6(2): 37-40.

LO, L. L., MCLAREN, D. G. and MCKEITH, F. K. 1992. Genetic analyses of growth, real-time ultrasound, carcass and pork quality traits in Duroc and Landrace pigs, Journal of Animal Science, 70(8): 23732386.

MARTIN, D., MURIEL, E., GONZALEZ, E. et al. 2008. Effect of dietary conjugated linoleic acid and monounsaturated fatty acids on productive, carcass and meat quality traits of pigs. Livestock Science, 117(2-3): 155-164.

MATOUŠEK, V., KERNEROVÁ, N., VÁCLAVOVSKÝ, J. et al. 2006. Field tests of selected combinations of final hybrids of pigs. Acta fytotechnica et zootechnica. 20: 20-23.

MLYNEK, J., IMRICH, I., VAVRIŠÍNOVÁ, K. et al. 2009. Use of fodder containing gm plants and their influence on production parameters in pigs. Research in Pig Breeding, 3(1): 23-31.

NEWCOM, D. W., STALDER, K. J., BAAS, T. J. et al. 2004. Breed difference and genetic parameters of myoglobin concentration in porcine longissimus muscle. Journal of Animal Science, 82: 2264-2268.

NOVOTNI-DANKO, G., BALOGH, P., HUZSVAI, L., GYŐRI, Z. 2015. Effect of feeding liquid milk supplement on litter performances and on sow back-fat thickness change during the suckling period. Archives of Animal Breeding, 58: 229-235.

OLIVAS, J. A., DÍAZ-TENORIO, L. M., MUNGUÍA-XÓCHIHUA, J. et al. 2017. Quality indicators in pork meat from different commercial center of Ciudad Obregón, Sonora (México). Nacameh, 11(2): 50-57.

RENAUDEAU, D. and MOUROT, J. 2007. A comparison of carcass and meat quality characteristics of Creole and Large White pigs slaughtered at $90 \mathrm{~kg}$ BW. Meat Science, 76(1): 165-171.

RUIZ DE HUIDOBRO, F., MIGUEL, E., ONEGA, E., BLÁZQUEZ, B. 2003. Changes in meat quality characteristics of bovine meat during the first 6 days post mortem. Meat Science, 65(4): 1439-1446.

RUUSUNEN, M., PUOLANNE, E., SEVON-AIMONEN, M. L. et al. 2012. Carcass and meat quality traits of four different pig crosses. Meat Science, 90(3): 543-547.

SERRANO, M. P., VALENCIA, D. G., FUENTETAJA, A. et al. 2008. Effect of gender and castration of females and slaughter weight on performance and carcass and meat quality of Iberian pigs reared under intensive management systems. Meat Science, 80(4): 1122-1128.

SLÁDEK, L., MIKULE, V., ČECHOVÁ, M., CHLÁDEK, G. 2008. An influence of hybrid combination and sex on growth ability of carcass pigs. Research in Pig Breeding, 2(1): 21-25.

SUZUKI, K., IRIE, M. M., KADOWAKI, H. et al. 2005. Genetic parameter estimates of meat quality trans in Duroc pigs selected for average daily gain, longissimus muscle area, backfat thickness and intramuscular fat content. Journal of Animal Science. 83(9): 2058-2065.

ŠIMEK, J. and STEINHAUSER, L. 2001. Barva masa. Maso, 4: 35-38.

ŠIMEK, J., GROLICHOVÁ, M., STEINHAUSEROVÁ, I. et al. 2004. Carcass and meat quality of selected final hybrids of pigs in the Czech Republic. Meat Science, 66(2): 383-386.

ŠPRYSL, M., ČÍTEK, J., STUPKA, R. et al. 2011. The effect of diet composition on slaughter value and quality of pig fat. Research in Pig Breeding, 5(2): 38-42.

THOMAS, R., BANIK, S., BARMAN, K. et al. 2019. Profiles of colour, minerals, amino acids and fatty acids in Asha, the triple cross (Ghungroo $\times$ Hampshire $\times$ Duroc) fattener pig variety. Indian Journal of Animal Research, 53(4): 435-440. 
VÁCLAVKOVÁ, E. and BEČKOVÁ, R. 2009. Carcass value and meat fatty acid composition of fattening gilts and barrow. Research in Pig Breeding, 3(2): 36-39.

VALIŠ, L., VÍTEK, M., DAVID, L. et al. 2008. Lean meat content and distribution in pig carcasses. Research in Pig Breeding, 2(2): 39-41.

VÍTEK, M., DAVID, L., VALIŠ, L. et al. 2012. The effect of sex, weight and lean meat content on the pig carcass realization. Research in Pig Breeding, 6(2): 97-101.

WOOD, J. D., ENSER, M., FISHER, A. V. et al. 2008. Fat deposition, fatty acid composition and meat quality. A review. Meat Science, 78: 343-358. 